\title{
Assessment of concrete anisotropy by means of compression and indirect tensile tests
}

\section{Avaliação da anisotropia do concreto utilizando ensaios de compressão e tração indireta}
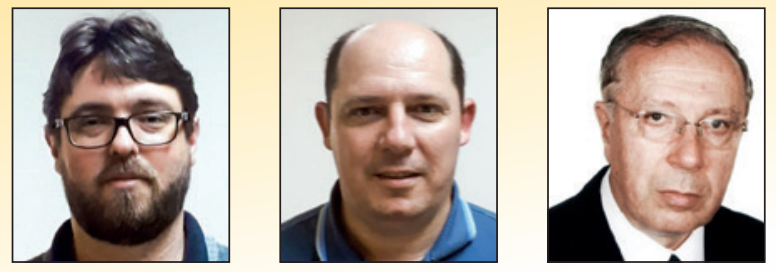

\author{
L. E. KOSTESKI \\ luiskosteski@gmail.com \\ https://orcid.org/0000-0002-5168-6909 \\ E. MARANGON a \\ ederlimarangon@gmail.com \\ https://orcid.org/0000-0003-0812-8095 \\ J. D. RIERA b \\ jorge.riera@ufrgs.br \\ https://orcid.org/0000-0002-4902-237X
}

\begin{abstract}
In reinforced concrete structural analysis and design it is normally assumed that the material is globally isotropic and homogeneous. Local departures from this model generally exert a minor influence on observed response and are therefore disregarded. There is overwhelming evidence, however, that in normal concrete there is some degree of meso-scale orthotropic behavior, which results from gravitational effects during concrete casting and hardening. In the present paper, results of compression tests, as well as indirect tensile tests using cylindrical samples, are reported. These tests confirm that both the unconfined compressive strength as well as the indirect tensile strength determined on cylindrical samples are perceptibly influenced by the angle between the sample axis and the vertical orientation during casting. It was determined that the ratio between the unconfined compressive strength of a C50 concrete mix measured in cylindrical samples cast in horizontal position and the strength of samples cast in horizontal position is on average 0.85 . Similarly, the tensile strength of concrete in the vertical direction is, on average, also about $15 \%$ smaller than the strength determined employing standard laboratory tests.
\end{abstract}

Keywords: concrete anisotropy, compressive strength, brazilian test, nonhomogeneous quasi-fragile materials, fracture.

\section{Resumo}

$\mathrm{Na}$ análise e projeto estrutural de concreto armado, normalmente se assume que o material é isotrópico e homogêneo. As caraterísticas pontuais das estrutura, geralmente exercem pouca influência no comportamento das mesmas, portanto normalmente são desconsideradas. No entanto, existem muitas evidencias de que, na mesoescala, o concreto convencional apresenta algum grau de comportamento ortotrópico, que resulta do efeito gravitacional durante o lançamento o endurecimento do concreto. No presente trabalho são apresentados os resultados de ensaios de compressão axial e de tração por compressão diametral em corpos de prova cilíndricos. Os resultados destes ensaios confirmam que ambas, as resistências à compressão axial e à tração indireta, são perceptivelmente influenciadas pelo ângulo entre o eixo do corpo de prova e a direção de lançamento do concreto. Foi observado que a relação entre a resistência à compressão axial de um concreto de classe C50 obtida em cilindros moldados na posição horizontal e moldados na posição vertical é, em média, 0,85. Da mesma forma, a resistência à tração do concreto na direção vertical é, em média, cerca de 15\% menor do que a resistência determinada empregando testes laboratoriais padrão.

Palavras-chave: anisotropia do concreto, resistencia à compressão, ensaio brasileiro, materiais quase frágeis não homogêneos, fratura. 


\section{Introduction}

In predictions of both static and dynamic response of concrete and reinforced concrete structures, the assumption of global isotropic material behavior is usually accepted. In fact, although there is considerable uncertainty concerning its validity after extensive fracture occurs, concrete isotropy is a standard assumption in structural analysis and design. It is widely recognized, however, that the in situ compressive strength of drilled concrete cores in the direction normal to the direction of casting is slightly smaller than the strength in the vertical direction. However, in spite of the evidence that in normal concrete there is some degree of meso-scale orthotropic behavior, in reinforced concrete structural analysis and design it is usually assumed that that the material is globally isotropic and homogeneous. Local departures from this model generally exert a small influence on observed response and are therefore disregarded. This anisotropic behavior may nevertheless affect structural response predictions in some special situations, as discussed by Riera et al. ${ }^{1}$ in connection with applications of the Lattice Discrete Element Method (LDEM). The effect may also be relevant in some experimental studies concerned with the strength of concrete walls subjected to punching loads (impact), which is influenced by the tensile strength in the direction normal to the wall middle surface. Although the latter are in a vertical position, for construction convenience the concrete plates are cast in horizontal position.

Evidence concerning the anisotropy of concrete in relation to the direction of casting has been repeatedly observed in the last half century, but remains curiously unrecognized. Hughes and $\mathrm{Ash}^{2}$, for example, report large differences between both the concrete strength, measured both under uniaxial tension and compression, in vertical and horizontal directions. Ozyildirim and Carino ${ }^{3}$ recently observed that weak interfacial regions occur more frequently under coarse aggregate particles, due to bleeding and other causes. As a consequence, in normal concrete horizontal initial fractures - not produced by load applications - may be expected to be more numerous than fractures in other orientations, resulting in a smaller compressive strength in the orientation parallel to the predominant orientation of the cracks, that is, the horizontal plane, than the compressive strength in the vertical direction ${ }^{4,5}$. This fact has been widely verified in pavement and highway construction: AASHTO T2 $24^{6}$ instructions clearly state that the strength of cores drilled in directions parallel to a horizontal plane tends to be lower than the strength of cores drilled in the vertical direction. The previous considerations lead to two important conclusions: first, horizontal cracks tend to close under vertical compression and therefore their presence should not influence either experimental determinations of the (vertical) unconfined compressive strength. On the other hand, these horizontal cracks should cause a reduction of the influence of confining stresses on the vertical strength, in relation to the effect that might be expected in an isotropic material.

Since the consideration of this factor may be important in some structural problems, the authors previously additional experimental studies in order to quantify, by means of compression tests of cubic laboratory samples, the degree of anisotropy that may be expected in concrete structures ${ }^{7}$. Those initial studies suggested that the effect may result in errors as high as $10 \%$ in the estimated carrying capacity of concrete elements and were expanded in the present contribution, in which results of compression tests, as well as indirect tensile tests using cylindrical samples, are reported. These tests confirm that both the unconfined compressive strength as well as the indirect tensile strength determined on cylindrical samples are perceptibly influenced by the angle between the sample axis and the vertical orientation during casting.

In connection with compression tests on cubic samples, the results of Kosteski et al. ${ }^{7}$ lead to evidence concerning the fact that the strength measured in the direction of casting, exceeds the strength measured in a direction orthogonal to the direction of casting, coincident with extensive results reported by Yi et al. ${ }^{8}$. These authors, who continued earlier studies of $\mathrm{Kim}$ and $\mathrm{Eo}^{9}$, were concerned mainly with size and shape effects of samples used in different codes to assess fc', the compressive strength of concrete measured in standard cylindrical samples and somehow overlooked the fact that concrete always presents a perceptible degree of anisotropy, not only testing samples.

The effect was simulated with encouraging results by Riera et al. ${ }^{1}$, by reducing the specific fracture energy Gf of DEM elements oriented in the vertical direction, which confirms the need to collect additional experimental evidence on the subject, in order to reliably quantify the degree of anisotropy in conventional concrete.

Furthermore, there is ample evidence that the strength, modes of failure and the permeability of concrete, are significantly influenced by interfaces between the cement paste and the aggregates, mainly with coarse aggregates ${ }^{10,11}$. The order hand, there are lack of understanding about these phenomenon, interfaces, and a very little attempts have been made to characterize the mechanical properties of this zone.

\section{Preparation of cylindrical samples}

As previously noted, the available evidence on the meso-scale anisotropic behavior of concrete is based mainly on tests of concrete cores retired from built structures. The authors are not aware of laboratory investigations designed to examine this effect before the pilot study described by Kosteski et al. ${ }^{7}$, in which two conventional concrete mixes, designated as materials C30 and C50, were employed in the preparation of the samples. The compositions of both concretes are indicated in Table 1. Brazilian Portland Cement type CP V-ARI was used in all samples. The sand, extracted from the Ibicuí River (RS, Brazil), had particles with high quartz content in the range between $0.15 \mathrm{~mm}$ and $4.8 \mathrm{~mm}$ and fineness modulus 1.38 , while the coarse aggregate was of basaltic origin with a

\section{Table 1}

Composition of mixes employed in the study

\begin{tabular}{ccc}
\hline Material & C30 & C50 \\
\hline Portland cement $\left[\mathrm{kg} / \mathrm{m}^{3}\right]$ & 319.1 & 454.1 \\
Sand $\left[\mathrm{kg} / \mathrm{m}^{3}\right]$ & 820.2 & 921.2 \\
Coarse aggregate with $\mathrm{d}_{\text {max }}=19 \mathrm{~mm}$ & 1113.7 & 1049.0 \\
{$\left[\mathrm{~kg} / \mathrm{m}^{3}\right]$} & 217.0 & 199.8 \\
Water $\left[\mathrm{kg} / \mathrm{m}^{3}\right]$ & - & 1.09 \\
Superplastifyer $\left[\mathrm{kg} / \mathrm{m}^{3}\right]$ & 2444.6 & 2470.1 \\
Specific mass $\left[\mathrm{kg} / \mathrm{m}^{3}\right]$ & 140 & 110 \\
Slump $[\mathrm{cm}]$ & & \\
\hline
\end{tabular}


maximum size of $19 \mathrm{~mm}$. Policarboxilate based superplastifyer with $30 \%$ solids content was added to the C50 concrete mix. The water/ cement ratio was 0.44 for the $\mathrm{C} 50$ concrete. The concrete was prepared in an inclined axis mixer at the Civil Engineering Laboratories, UNIPAMPA (Alegrete Campus), Brazil. Results for concrete samples reported in this paper were prepared with C50 mix only. The concrete consistency, measured with Abrams cone, was $60 \mathrm{~mm}$. The compaction concrete was made through the use of the bar of Abrams' cone kit. Two concrete layers were made and were applied kicks on each layer until a slightly regularized surface. In PVC tubes the compaction was made though rectangular openings located on the upper sides of the tubes, using the same equipment, bar of Abrams.

It is important to note that in the experiments reported in this paper, Brazilian Portland Cement type CP $\vee$ was used because the cement used in the previous study7, namely Cement type CP V-ARI, was not available at the time of samples preparation.

Preparation of the cylindrical samples posed a new problem: whether the vertical axis might be rotated after or before concrete casting. It was decided that to more closely reproduce the behavior observed in the field, the vertical axis should not be altered during casting and curing, which led to the need to cast the concrete mix in cylindrical molds lying horizontally on a laboratory, as shown in Figure 1. Thus, a second set of ten $(100 \mathrm{~mm}$ diameter $\times 200 \mathrm{~mm}$ height) samples were prepared to determine the strength in horizontal direction, as shown in Figure 1.

For this purpose, the samples were molded in two segments of a PVC tube, approximately $1.15 \mathrm{~m}$ long, from which five $200 \mathrm{~mm}$ long samples were cut after 28 days by means of a circular saw. The concrete mix was poured through rectangular openings located on the upper sides of the tubes, as shown in the Figure 1. 24 hours after casting, the reference samples were removed from the molds and placed until testing in a humid chamber with controlled humidity and temperature. The two PVC tube segments had their end covers removed and remained covered during 7 days with a permanently soaked cloth. Afterwards, the tubes were transferred to the humid chamber. After 28 days the samples were cut to their final $200 \mathrm{~mm}$ length. The circular saw used for that purpose, as well as the ten samples before removing the molds, are shown in Figure 2. The diameter of these samples was $98.5 \mathrm{~mm}$.

The samples, before submitted to compression testes, were rectified to regularize its surface.
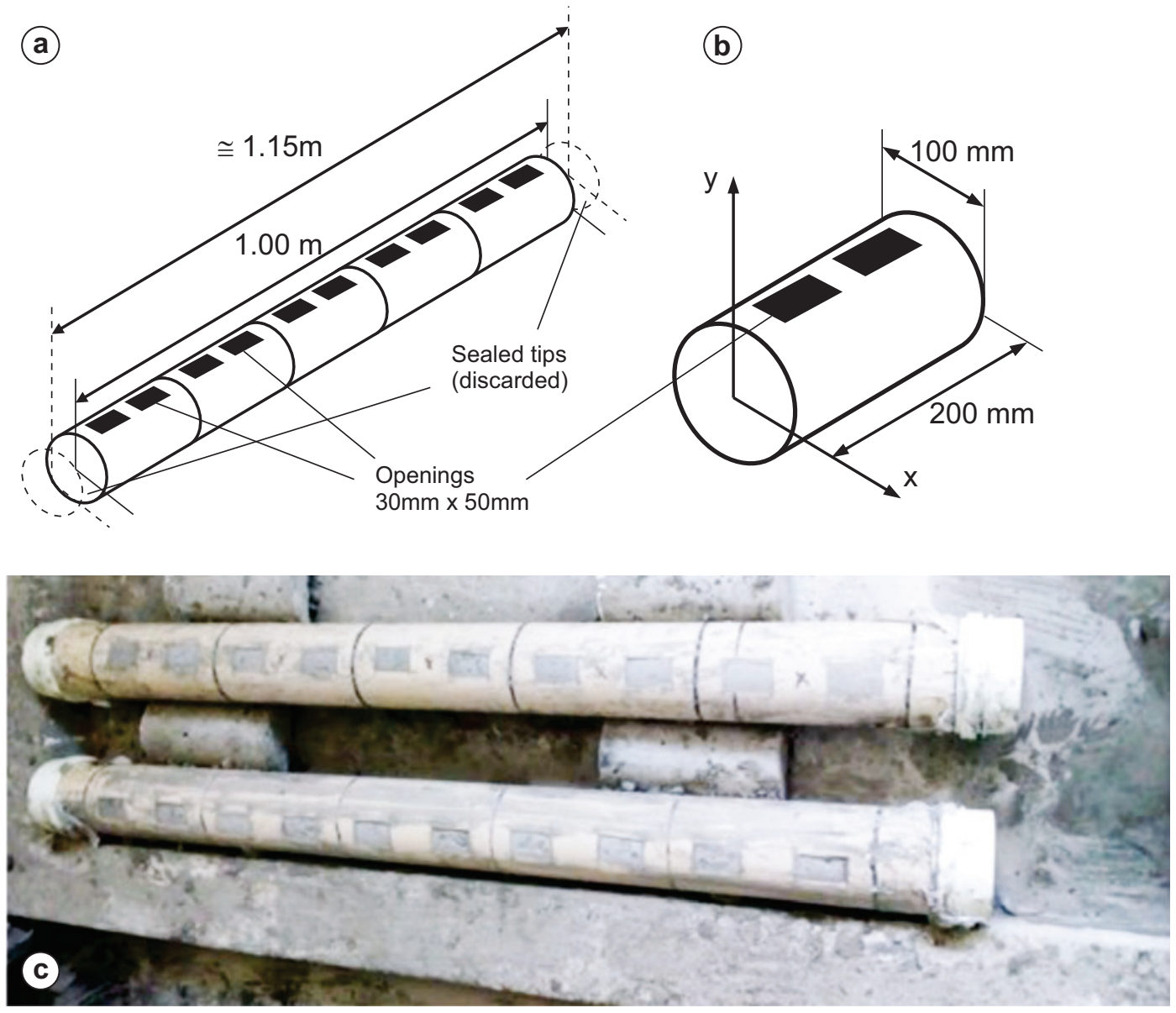

\section{Figure 1}

(a) Sketch of PVC pipe employed as mold of the cylindrical horizontal samples, (b) Approximate final dimensions of the test samples, (c) view of the molds after casting 

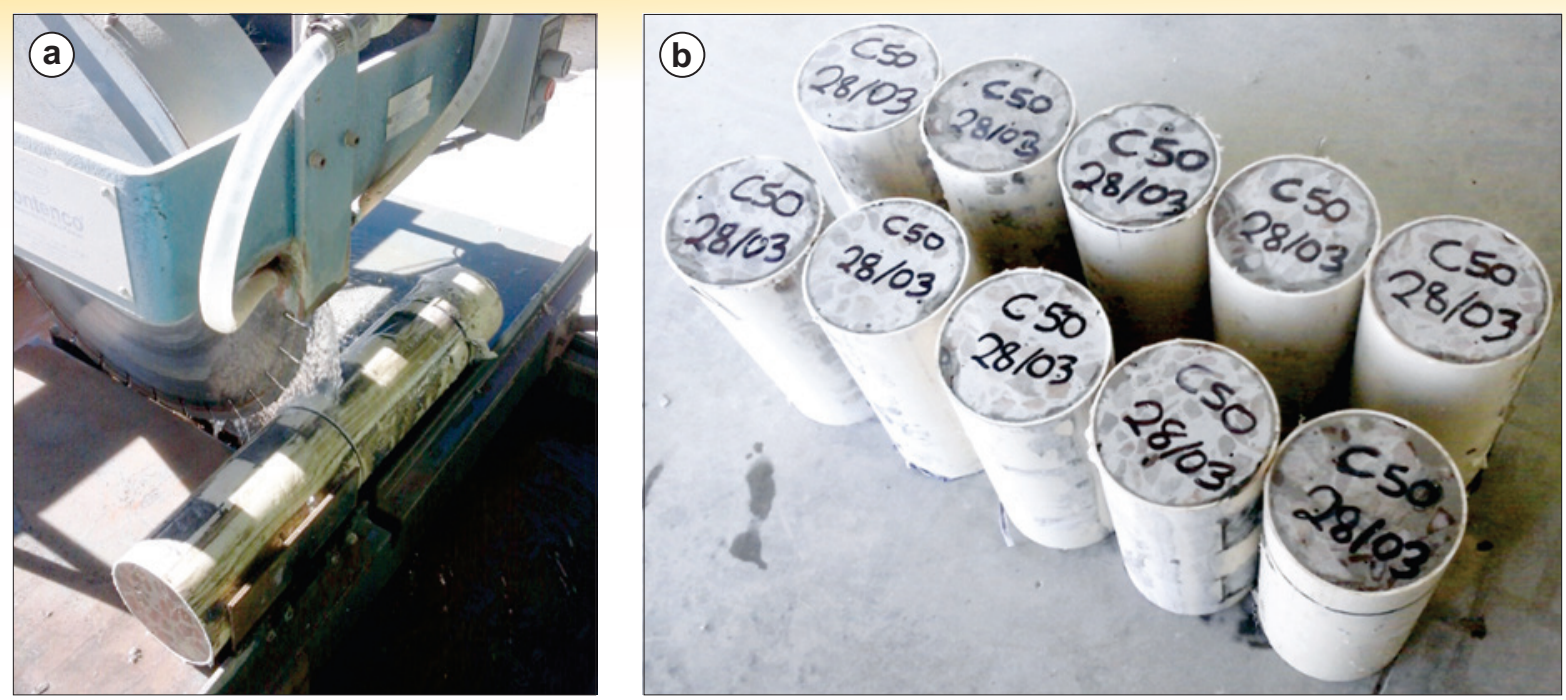

\section{Figure 2}

(a) Circular saw, (b) Samples cast with cylinder axes in horizontal position

\section{Results and discussions}

This section contains the experimental results of compression and indirect tensile tests for both the standard reference samples, as well as the corresponding strengths measured in horizontally cast specimens.

\subsection{Compression tests}

The samples cast in the standard forms were tested first under unconfined compression. Both the observed compressive strength as well as the failure modes of the reference samples confirm the expected response, as illustrated by Figures 3 .

The compressive strengths measured in standard cylindrical samples are indicated in Table 2. Figure 4 shows the stress vs. strain graphs for the five tested samples. On the other hand, one of the samples cast in horizontally placed cylinders (as shown in Figure 1 and 2), identified as sample S3, reached a
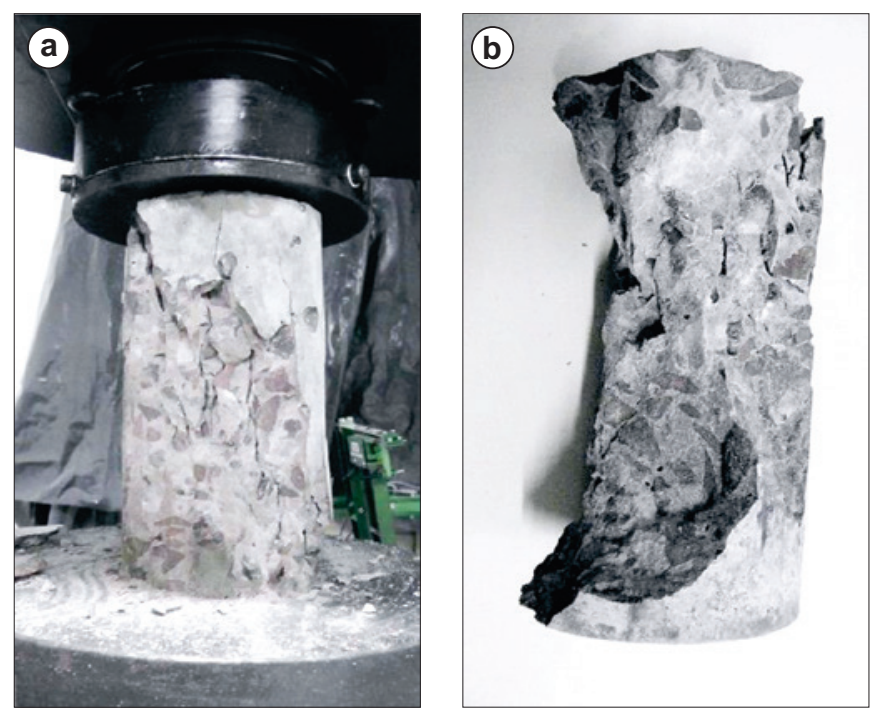

\section{Figure 3}

(a) Sample in testing machine showing failure mode, (b) Another sample compressive strength of $51,39 \mathrm{MPa}$. The rest of the samples were considered with fabrication defects - the mean strength of the five samples was only $38.78 \mathrm{MPa}$ - and hence individual results were not reported herein.

The rupture configurations of samples cast in horizontal position

\section{Table 2}

Compressive strength measured in conventional samples

\begin{tabular}{ccccc}
\hline \multicolumn{2}{c}{ Reference samples } \\
$\begin{array}{c}\text { Compressive strength } \\
\text { [MPa] }\end{array}$ & $\begin{array}{c}\text { Mean } \\
\text { strength } \\
\text { [MPa] }\end{array}$ & $\begin{array}{c}\text { Standard } \\
\text { deviation }\end{array}$ & CV \\
\hline S1 & 65.09 & & & \\
S2 & 65.48 & & & \\
S3 & 61.91 & 64.04 & 1.59 & $2.48 \%$ \\
S4 & 62.80 & & & \\
S5 & 64.94 & & & \\
\hline
\end{tabular}

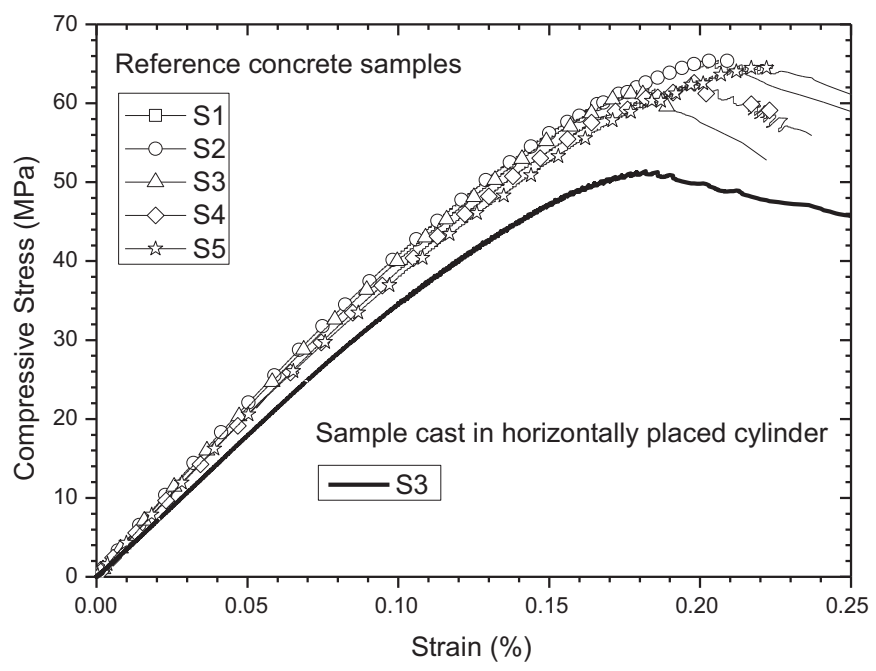

Figure 4

Stress vs. strain plots for the reference concrete samples and sample S3, cast in horizontally placed cylinder 

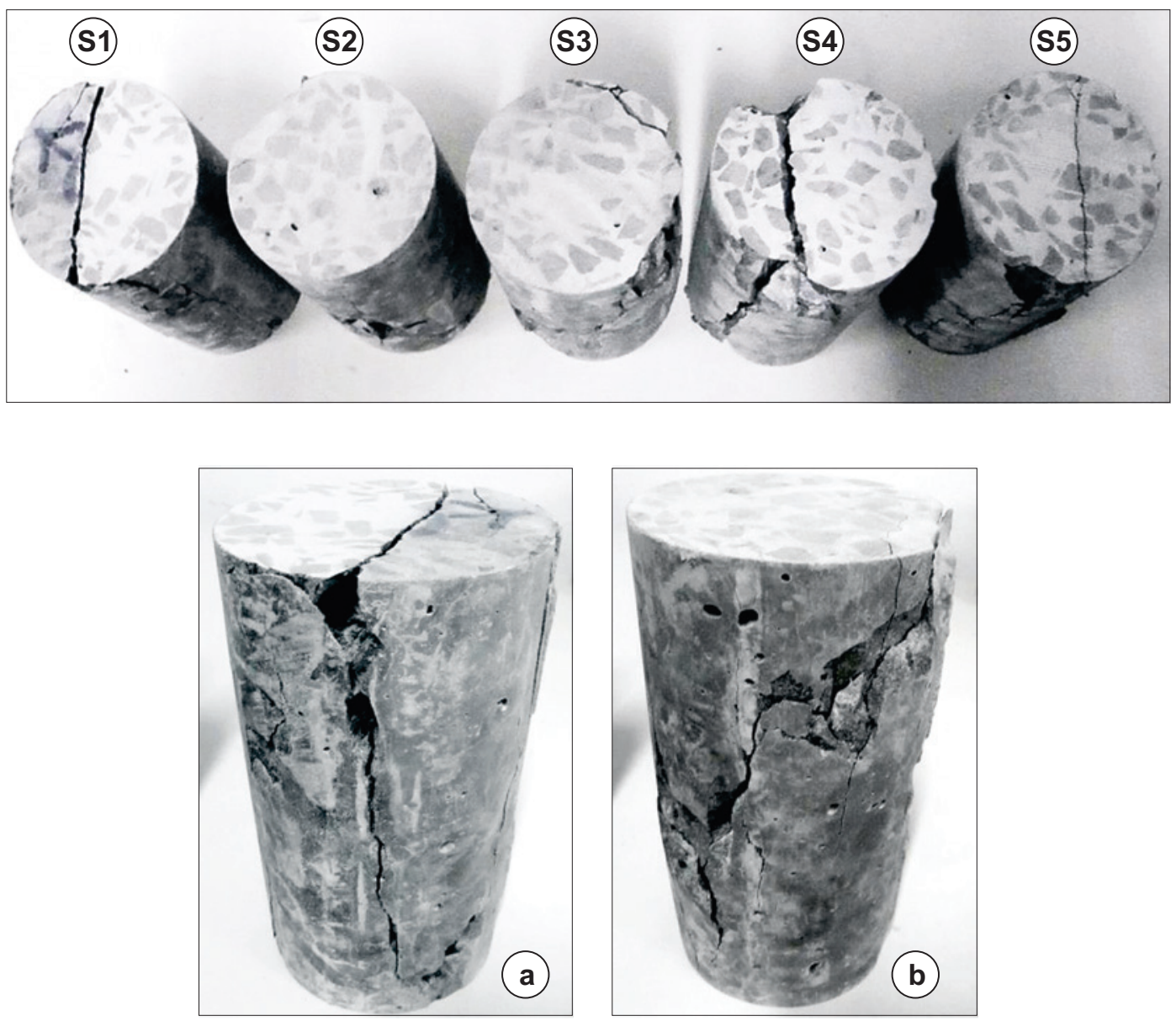

\section{Figure 5}

View of failure configurations of samples cast in horizontal position: (above) top view of all samples, (below) (a) Sample S1, (b) Sample S2

are shown in Figure 5. It may be seen that failure often occurs due to low tensile strength normal to a vertical plane in the central portion of the cylinder, thus reducing the influence of friction at the end plattens.

The strength of sample S3 is roughly $20 \%$ smaller than the mean strength measured in conventional tests, result that suggests a strength reduction larger than that observed in cubic samples by Kosteski et al. ${ }^{7}$, but still within the expected range.

\section{Table 3}

Indirect tensile strengths measured in reference conventional tests

\begin{tabular}{|c|c|c|c|c|}
\hline \multirow{2}{*}{\multicolumn{2}{|c|}{$\begin{array}{c}\text { Reference samples } \\
\text { Indirect tensile strength } \\
\text { [MPa] }\end{array}$}} & \multirow{3}{*}{$\begin{array}{c}\text { Mean } \\
\text { strength } \\
\text { [MPa] }\end{array}$} & \multirow{2}{*}{$\begin{array}{l}\text { Standard } \\
\text { deviation }\end{array}$} & \multirow[b]{2}{*}{ CV } \\
\hline & & & & \\
\hline S1 & 4.35 & & \multirow{5}{*}{0.92} & \multirow{5}{*}{$16.92 \%$} \\
\hline S2 & 5.78 & \multirow{4}{*}{5.46} & & \\
\hline S3 & 6.51 & & & \\
\hline S4 & 4.64 & & & \\
\hline S5 & 6.03 & & & \\
\hline
\end{tabular}

\subsection{Indirect tensile failure by diametral compression}

The remaining five samples were tested under diagonal compression (Brazilian test), with the results presented in Table 3, which shows the indirect tensile strength measured in the reference conventional tests, while Table 4 presents the tests results for samples cast in PVC tubes with the axis in horizontal position.

\section{Table 4}

Indirect tensile strengths measured in samples cast in horizontal PVC tubes

\begin{tabular}{ccccc}
\hline $\begin{array}{c}\text { Samples cast in } \\
\text { horizontal position }\end{array}$ & $\begin{array}{c}\text { Mean } \\
\text { strength } \\
\text { [ndirect tensile strength } \\
\text { [MPa] }\end{array}$ & $\begin{array}{c}\text { Standard } \\
\text { deviation }\end{array}$ & CV \\
\hline S1 & 5.49 & & & \\
S2 & 4.89 & & & \\
S3 & 3.89 & 4.60 & 0.61 & $13.29 \%$ \\
S4 & 4.29 & & & \\
S5 & 4.45 & & & \\
\hline
\end{tabular}



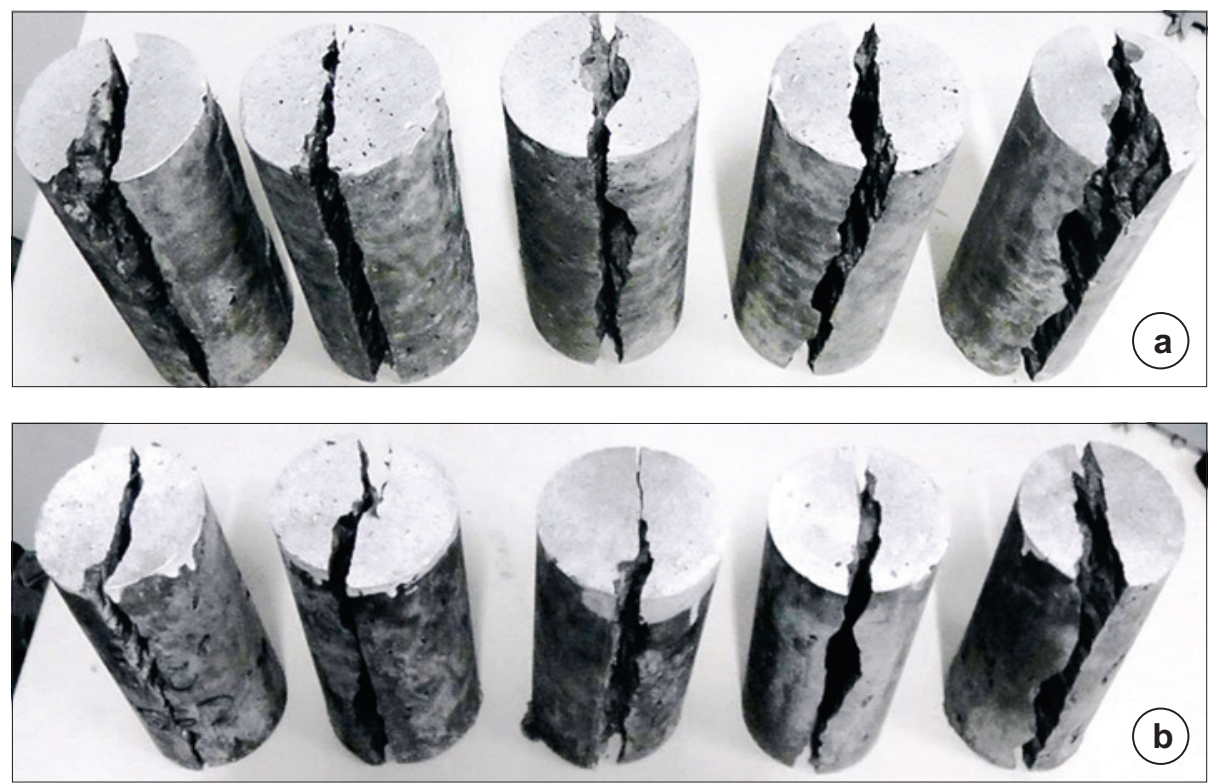

Figure 6

Failure modes of cylinders tested in diametral compression, (a) reference tests, (b) samples cast in horizontal position (see Figure 1)

\section{Table 5}

Compressive strength measured in additional conventional tests with standard samples

\begin{tabular}{ccccc}
\hline \multicolumn{2}{c}{$\begin{array}{c}\text { Reference samples } \\
\text { Compressive strength } \\
\text { [MPa] }\end{array}$} & $\begin{array}{c}\text { Mean } \\
\text { strength } \\
\text { [MPa] }\end{array}$ & $\begin{array}{c}\text { Standard } \\
\text { deviation } \\
\text { [MPa] }\end{array}$ & CV \\
\hline S1 & 65.93 & & & \\
S2 & 64.30 & & & \\
S3 & - & 64.93 & 1.03 & $1.58 \%$ \\
S4 & 65.67 & & & \\
S5 & 63.83 & & & \\
\hline
\end{tabular}

Differently from the unconfined compression tests, all indirect tensile strength test results are consistent and compatible with available experimental evidence. Moreover, the failure configurations shown in Figure 6, as well as the CVs (shown in Tables 3 and 4) are quite similar in both cases. The reduction of around $15 \%$ of the indirect tensile strength is also compatible with experimental and theoretical (numerical) models ${ }^{7}$.

\section{Additional tests}

Due to the deficiencies observed in the tests for horizontally cast cylinders, a second set of samples was prepared employing the same C50 mix, slightly modified by increasing the amount of superplastifyer $(2,95 \mathrm{~kg} / \mathrm{m} 3)$, without changing the other components. The density of the mix, $\mathrm{y}=2470 \mathrm{~kg} / \mathrm{m}^{3}$, remained practically unaltered, but the concrete consistency measured with Abrams cone was augmented to $110 \mathrm{~mm}$. Five conventional $200 \mathrm{~mm} \times 100 \mathrm{~mm}$ samples were cast in steel forms, three additional samples in PVC forms, all of them in the vertical position, to confirm that the rough- ness of the walls or the cuts of the long concrete cylinder did not exert any perceptible influence on tests results. A second set of five samples was prepared, to determine the strength in horizontal direction, employing the PVC tube shown in Figure 1.

The compressive strengths measured in standard cylindrical samples are listed in Table 5 . Figure 7 shows the stress vs. strain curves for four samples. The results for sample S3 were deleted from the set because it was detected an experimental error in this test. The results for the second set of samples are almost identical to those indicated in Table 2.

The samples cast in PVC tubes in the vertical position were next

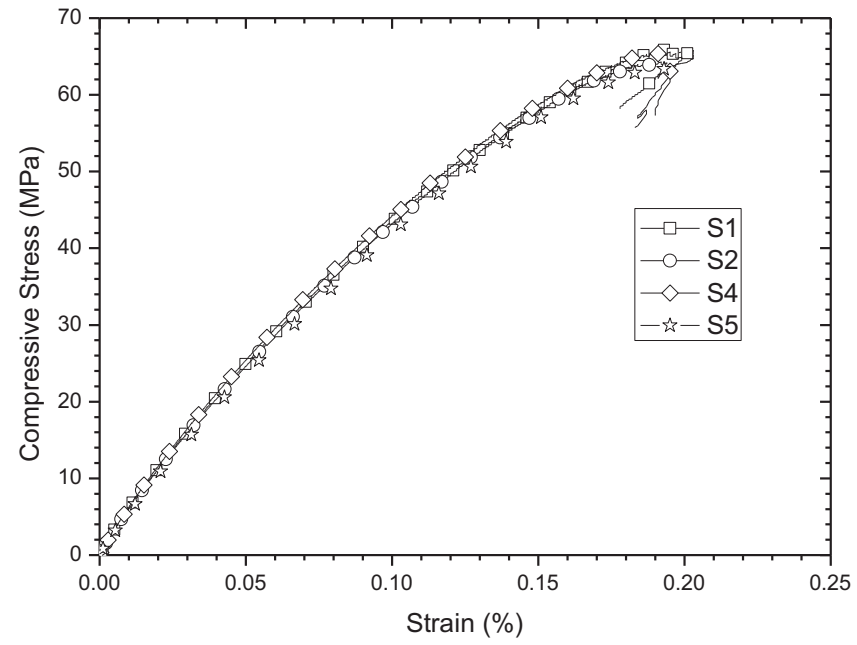

\section{Figure 7}

Stress vs. strain plots for the reference concrete samples 


\section{Table 6}

Compressive strength measured in samples cast in vertical PVC tubes

\begin{tabular}{ccccc}
\hline \multicolumn{2}{c}{$\begin{array}{c}\text { Reference samples } \\
\text { Compressive strength } \\
\text { [MPa] }\end{array}$} & $\begin{array}{c}\text { Mean } \\
\text { strength } \\
\text { [MPa] }\end{array}$ & $\begin{array}{c}\text { Standard } \\
\text { deviation } \\
\text { [MPa] }\end{array}$ & CV \\
\hline $\mathrm{S} 1^{*}$ & 58.62 & & & \\
$\mathrm{~S} 2$ & 63.92 & 61.32 & 2.65 & $4.32 \%$ \\
$\mathrm{~S} 3{ }^{*}$ & 61.42 & & & \\
\hline
\end{tabular}

\section{Table 7}

Compressive strength of additional samples cast in horizontal PVC tubes

\begin{tabular}{ccccc}
\hline \multicolumn{2}{c}{ Reference samples } \\
\hline $\begin{array}{c}\text { Compressive strength } \\
\text { [MPa] }\end{array}$ & $\begin{array}{c}\text { Mean } \\
\text { strength } \\
\text { [MPa] }\end{array}$ & $\begin{array}{c}\text { Standard } \\
\text { deviation } \\
\text { [MPa] }\end{array}$ & CV \\
\hline S1 $^{*}$ & 41.85 & 40.58 & 1.82 & $4.44 \%$ \\
S2* & 39.30 & & & \\
\hline S3 & 53.29 & & 0.66 & 1.21 \\
S4 & 54.52 & 54.04 & & \\
S5 & 54.30 & &
\end{tabular}

*S1 and S2 are the samples located at the ends of the PVC tube

subjected to standard unconfined compression tests with the results presented in Table 6 . The corresponding stress-strain curves are shown in grey in Figure 8.

Differences between the results presented in Table 6 (PVC forms) with those shown in Tables 2 and 5 (standard metallic forms) are not statistically significant. In fact, one-way Analysis of Variance test with 0.05 significance level and 0.95 degree of confidence allows rejecting the hypothesis that sample preparation, including the type of form, may have influenced the test results. The mean

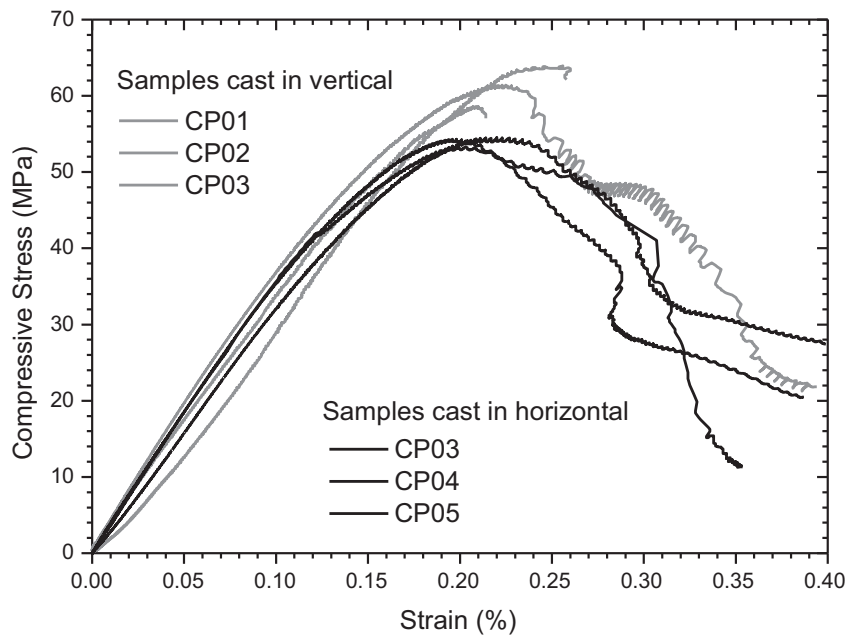

Figure 8

Stress vs. strain plots for additional samples cast in vertical (grey) and horizontal (black) PVC

value of the compressive strength for samples cast in vertical position is then considered equal to the average of the mean values indicated in Tables 5 and 6 , that is, $63.38 \mathrm{MPa}$.

Table 7 lists the compressive strengths of samples cast in PVC tubes in horizontal position, while the corresponding stress vs. strain curves are shown in black in Figure 8.

The assumption that the location of the sample within the tube does not affect the sample strength cannot be accepted: there is a clear reduction of the strength of the samples at both ends of the PVC tube, which may be due to increased difficulties to compact the mix during casting or to other effects. Those samples were thus rejected, while the remaining three samples at the centre of the PVC tube may be admitted to be similar, characterized by a mean

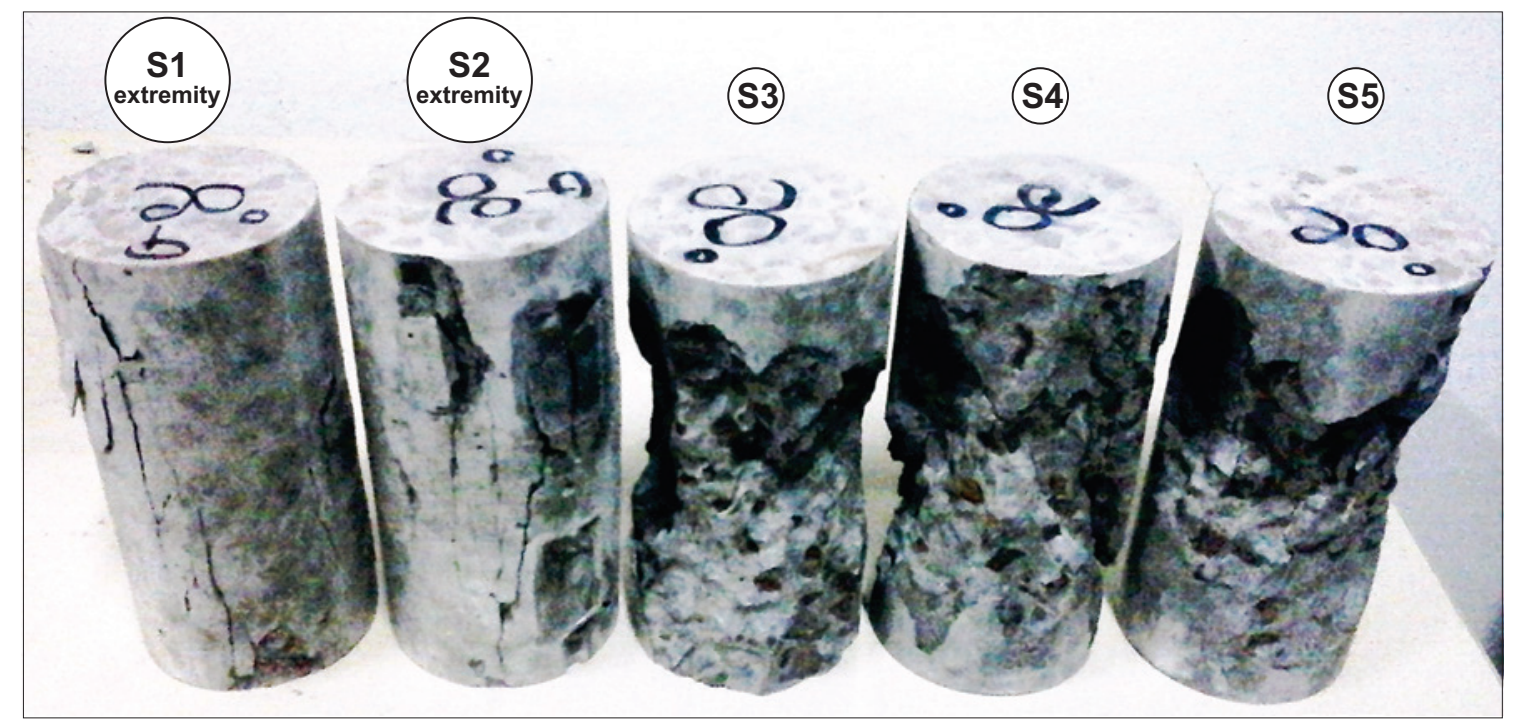

Figure 9

View of failure configurations of additional samples cast in horizontal position 
compressive strength equal to $54,04 \mathrm{MPa}$. The ratio between the compressive strengths of cylinders cast in horizontal and vertical positions results in consequence equal to 0.8525 . The result is statistically significant (ANOVA test, $0.05 \%$ significance level). Moreover, the ratio between compressive strengths in the horizontal and vertical directions indicated previously is very close to the ratio determined for the tensile strengths $(0.8425)$ determined employing the Brazilian test for samples cast in horizontal and vertical positions, confirming the basic hypothesis concerning concrete failure under different loading conditions.

Figure 9 shows the final rupture configurations of samples cast in horizontal position. The figure shows that in the additional tests, samples located during casting at the center of the tube are characterized by the expected conical failure configurations, while samples at the ends of the PVC tube exhibit vertical fractures, i.e. a column like failure. The last configurations are similar to the failure modes shown in Figure 5 for the first set of samples, suggesting deficient concrete compaction in those samples or the presence of unusually large initial fractures. Another relevant issue in the additional tests is that the samples cast in vertical position showed a more abrupt or explosive failure. On the other hand, when horizontally cast samples were tested, rupture was softer. This behavior may be due to less unstable crack propagation, due to the existing cracks (created on the concrete curing process around the grains) and their coalescence, caused mainly by the propagation of secondary cracks that arise at the tips of the preexisting cracks. Finally, Figure 9 shows evidence of an inter-granular rupture (S1 e S2), which is attributed at the cleavage that follows the joints of the grains, produced by the incompatibility of deformation between Portland cement paste and the adjacent sand/stone grains, or because those regions present stress concentrations. The samples with a conic failure are originated from nucleation, growth and coalescence of vacuum (emptiness) inside the crystals. These assumptions are supported by the stress-strain curves in Figure 8, in which it is shown that after peak stress, the curves from the horizontally cast samples present softer reduction of tension then the vertically cast samples.

\section{Assessment of tests on cubic and cylindrical samples}

It was determined in the present paper that the ratio between the unconfined compressive strength of a C50 concrete mix measured in cylindrical samples cast in horizontal position and the strength of samples cast in horizontal position is on average 0.85 . The result confirms available experimental and theoretical evidence and is attributed to the larger size or number of initial cracks, not induced by applied loading, located in approximately horizontal planes at the concrete paste-coarse aggregates interface. The value of this ratio essentially coincides with the average ratio 0.84 measured previously by Kosteki et al. ${ }^{7}$ with cubic samples, providing evidence that the sample geometry does not exert a significant influence on its determination.

Tests to determine the indirect tensile strength (Brazilian test) were also conducted, which led to a similar 0.84 average ratio between the strengths of samples cast in the horizontal position and the strength of samples cast in the standard vertical position. This result may be expected, since the predominant horizontal cracks, in vertically cast samples, are contained during the Brazilian test within planes that are not subjected to large normal stresses. A different situation occurs in horizontally cast samples, in which case the initial crack, responsible for the onset of the fracture process, may be located within a vertical plane during the test, causing a large reduction of the tensile strength. The variability of the results of the Brazilian test is also larger, since a causative initial crack at the paste-aggregate interface may be present in the sample or not.

\section{Conclusions}

It may be concluded, on the basis of the experimental results described in the paper and on previous field evidence, that the unconfined compressive strength of conventional concrete in orientations normal to the direction of casting and curing (vertical) is approximately $15 \%$ smaller that the strength determined in the standard compression test. Similarly, the tensile strength of concrete in the vertical direction, measured by means of the so-called Brazilian test, is on average also about $15 \%$ smaller than the strength determined employing standard laboratory tests. The resulting strength anisotropy is attributed to the occurrence of small fractures that develop in concrete during casting and curing, at the interfaces between the lower surface of coarse aggregate and the cement-sand paste.

These results imply the existence of a not necessarily negligible degree of anisotropy in concrete, to the authors' knowledge not yet considered in analytical or numerical predictions of the non-linear response of concrete structures. It should be noted that the results show evidence that the compressive strength and the indirect tensile strength exhibit resistant capacities with significant differences in relation to the direction of casting and loading. However, additional tests are being carried out with different classes of concrete strength, in order to determine more accurately this phenomenon.

\section{Acknowledgements}

The authors acknowledge the financial support of FAPERGS, CNPq and CAPES.

\section{References}

[1] Riera JD, Miguel LFF and Iturrioz I. Material models in applications of the Discrete Element Method (DEM) to 3D concrete compression. In Proceedings of 24th Conference on Structural Mechanics in Reactor Technology, SMiRT-24, BEXCO, 2017, August, Busan, Korea. p. 20-25.

[2] Hughes BP and Ash JE. Anisotropy and failure criteria for concrete. Matériaux et Construction. 2017, v 3, 6: 371-374.

[3] Ozyildirim C and Carino NJ (2006) Chapter 13: Concrete Strength Testing. In: Significance of Tests and Properties of Concrete and Concrete-Making Materials, STP169D-EB, ASTM International, West Conshohocken, PA, 2006, pp. 125-140.

[4] Neville AM. Properties of Concrete: Fourth edition. John Wiley \& Sons, Inc., New York, USA. 1996.

[5] Suprenant BA. An Introduction to Concrete Core Testing, Civil Engineering for Practicing and Design Engineers, 1985, v 4, No. 8: 607-615. 
[6] AASHTO (American Association of State Highway and Transportation Officials). T24. Methods of sampling and testing: obtaining and testing drilled concrete cores. Washington, DC: AASHTO. 2005.

[7] Kosteski LE, Marangon E, Riera JD, dos Santos FJK and Bandeira MVV. Assessment of concrete anisotropy in relation to the direction of casting. Revista Sul-americana de Engenharia Estrutural. 2018. v.15, p. 37-45.

[8] Yi S, Yang El and Choi JC. Effect of specimen sizes, specimen shapes, and placement directions on compressive strength of concrete. Nuclear Engineering and Design, Elsevier, 2005, 236: 115-127.

[9] Kim JK and Eo SH. Size effect in concrete specimens with dissimilar initial cracks. Mag. Concrete Res. 1990, 42 (153): 233-238.

[10] Jebli M, Jamin F, Malachanne E. Garcia-Diaz E and El Youssoufi MS. Experimental characterization of mechanical properties of the cement paste-aggregate interface in concrete. EPJ Web of Conferences 140, DOI: 10.1051/epjconf/201714012014.

[11] Gu X, Hong L, Wang Z and Lin F. Experimental study and application of mechanical properties for the interface between cobblestone aggregate and mortar in concrete. Construction and Building Materials. v 46. 2013; 156-166. 